\title{
Szczególna ochrona prawna żołnierzy w postępowaniach sądowych i egzekucyjnych w Księstwie Warszawskim
}

Armia Księstwa Warszawskiego była jednocześnie jego chlubą i ciężarem. Z jednej bowiem strony wojsko dawało poczucie siły i bezpieczeństwa, $z$ drugiej natomiast stanowiło ogromne obciążenie dla budżetu biednego państwa. Żołnierze Księstwa tworzący jego armię byli grupą społeczną o szczególnej pozycji prawnej. Najbardziej oczywistym tego przejawem były przepisy prawa karnego wojskowego. Poza tym szczególne normy określały status żołnierzy w ramach prawa konstytucyjnego, przede wszystkim w zakresie praw politycznych czy prawa cywilnego w części dotyczącej testamentów. Na wyjątkową ochronę żołnierze mogli też liczyć w ramach przepisów postępowania cywilnego.

Kilkakrotnie w omawianym okresie władze państwowe wprowadzały przepisy, których celem było zabezpieczenie interesów żołnierzy w postępowaniach wszczynanych i prowadzonych wobec nich przez sądy i organy egzekucyjne. Po raz pierwszy takie normy ustanowiła Komisja Rządząca. Wniosek w tej sprawie przygotował dyrektor sprawiedliwości Feliks Łubieński i przedłożył go na sesji w dniu 24 stycznia 1807 r. Projekt Łubieńskiego został przyjęty ostatecznie przez Komisję Rządzącą jako uchwała na sesji w dniu 30 stycznia. W tym obszernym akcie uregulowano zresztą nie tylko sytuację żołnierzy, ale także innych osób w związku z wyjątkową sytuacją, jaką były prowadzone wówczas działania wojenne. Według tej uchwały najszerszej ochronie podlegali żołnierze pełniący służbę w wojsku polskim i francuskim, jeńcy oraz osoby, na których ciążył obowiązek zaopatrzenia armii, a także inne osoby niepozostające w służbie wojskowej, ale na stałe przebywające przy oddziałach wojska oraz funkcjonariusze państwowi przebywający w ramach pełnienia swoich obowiązków za granicą. W uchwale 
Komisji w odniesieniu do osób należących do tak określonej grupy zakazano sądom przyjmowania pozwów i jakichkolwiek wniosków, których celem było wszczęcie procesów przeciwko nim. Poza tym nie można było wszczynać wobec żołnierzy i innych osób wskazanych wyżej egzekucji ani podejmować kroków, których celem było przymusowe wykonanie świadczeń wynikających z zawartych ugód. Wszelkie procesy przeciwko tym osobom miały być zawieszone. Warunkiem korzystania z ochrony w postępowaniu sądowym i egzekucyjnym był lojalny stosunek do wierzycieli. Nie podlegali bowiem ochronie ci dłużnicy, którzy rozporządzali swoim majątkiem na szkodę wierzycieli, ani ci, którzy celowo obciążali swój majątek, czy ci, którzy układali się z niektórymi swoimi wierzycielami kosztem pozostałych ${ }^{1}$.

Postanowienia zawarte w uchwale Komisji Rządzącej z dnia 30 stycznia 1807 r. dotyczyły spraw cywilnych, nie obejmowały natomiast postępowań o charakterze karnym. Możliwe więc było ściganie żołnierzy za popełnienie przestępstw podlegających rozpoznaniu przez sądy powszechne, czyli te, które działały poza strukturą sądownictwa wojskowego. Prawna ochrona żołnierzy miała trwać przez cały czas działań wojennych ${ }^{2}$.

Mimo zawarcia na początku lipca układów pokojowych w Tylży przepisy o prawnej ochronie żołnierzy w postępowaniach sądowych i egzekucyjnych nadal obowiązywały. Dopiero w listopadzie 1807 r., a więc po wprowadzeniu nowych struktur władzy według norm konstytucji, organy państwowe zajęły się tym problemem. Nastąpiło to na skutek interwencji ministra sprawiedliwości Łubieńskiego, który zwrócił się do króla Fryderyka Augusta o zajęcie stanowiska w kwestii dalszego obowiązywania przepisów uchwały Komisji Rządzącej z dnia 30 stycznia 1807 r. Monarcha, za pośrednictwem ministra sekretarza stanu Stanisława Brezy, polecił Radzie Stanu przedstawienie swej opinii w tej sprawie. Rada na posiedzeniu w dniu 28 listopada 1807 r. uznała, że żołnierze mogli być pozywani przed sądami powszechnymi (,cywilnymi”). Oznaczało to, że Rada Stanu nie widziała konieczności przedłużania prawnej ochrony żołnierzy ustanowionej przez Komisję Rządzącą. Uznała natomiast, że odrębnie należało potraktować egzekucję wyroków orzeczonych wobec nich. Według Rady żołnierze, którzy byli właścicielami nieruchomości (,posesjonatami”), mieli odpowiadać na normalnych zasadach,

${ }^{1}$ Materiaty do dziejów Komisji Rządzącej z r. 1807, t. I: Dziennik czynności Komisyi Rządzącej, wyd. M. Rostworowski, Kraków 1918, s. 508-509; H. Grynwaser, Pisma, t. I: Kodeks Napoleona w Polsce, Wrocław 1951, s. 113; W. Sobociński, Historia ustroju i prawa Księstwa Warszawskiego, Toruń 1964, s. 239, przyp. 1; J. Bardach, M. Senkowska-Gluck (red.), Historia państwa i prawa Polski, t. III, Warszawa 1981, s. 121; T. Mencel, Organizacja sądownictwa na ziemiach polskich w okresie Komisji Rządzacej (1807), „Przegląd Historyczny” 1950, nr XL, s. 239.

${ }^{2}$ Materiaty..., s. 508-510. Wymiar sprawiedliwości w wojsku należał, po ich utworzeniu, do rad gospodarczych. Zob. H. Eile, Administracja w wojsku Księstwa Warszawskiego, „Przegląd Intendencki" 1926, z. 3, s. 42; G. Zych, Armia Księstwa Warszawskiego 1807-1812 [Warszawa 1961], s. 42. 
zaś postępowanie egzekucyjne wobec nieposesjonatów mogło być prowadzone za pośrednictwem czy przy udziale dowódców zadłużonych żołnierzy ${ }^{3}$.

Król zgodził się ze stanowiskiem Rady Stanu i 12 grudnia 1807 r. wydał dekret w sprawie dalszego obowiązywania uchwały Komisji Rządzącej z dnia 30 stycznia 1807 r. Fryderyk August uchylił przepisy tej uchwały i zniósł prawną ochronę żołnierzy w postępowaniach przed sądami powszechnymi. Co ciekawe, dekret królewski dotyczył nie tylko spraw cywilnych, ale także karnych, co do których uchwała Komisji Rządzącej nie zakazywała przecież prowadzenia. Od daty wydania dekretu można więc było wnosić pozwy przeciwko wojskowym, odwieszeniu ulegały też sprawy, które do tej pory były zawieszone na podstawie uchwały Komisji. Odnośnie do prowadzenia postępowań egzekucyjnych w dekrecie postanowiono, że ,posiadający majątki odpowiadać z onychże będą, przeciw niemającym majątku, udać się winna strona na nich wyrok zyskująca w sądzie do zwierzchniej władzy wojskowej". W przepisach dekretu wyłączono więc właściwość organów egzekucyjnych w tych szczególnych wypadkach. Wierzyciele tej drugiej grupy żołnierzy mieli otrzymywać $1 / 4$ należnego ich dłużnikom żołdu. W porównaniu do sformułowań użytych w czasie dyskusji na sesji Rady Stanu w dniu 28 listopada 1807 r. w dekrecie z 12 grudnia posłużono się więc nieco inną terminologią wobec tej drugiej kategorii żołnierzy. Zamiast określenia „nieposesjonaci” pojawiła się kategoria żołnierzy ,niemających majątku”. Zmiana ta zapewne nie była przypadkowa. Gdyby bowiem możliwość egzekucji z żołdu przewidziano dla żołnierzy nieposesjonatów, czyli nieposiadających nieruchomości, prowadziłoby to do znaczącego ograniczenia przewidzianych prawem sposobów egzekucji. Wobec żołnierzy nieposesjonatów nie można by np. prowadzić egzekucji z ruchomości

W dekrecie z dnia 12 grudnia 1807 r. i w dyskusji na posiedzeniu Rady Stanu w dniu 28 listopada 1807 r. jako adresatów regulacji wskazano „wojskowych”.

${ }^{3}$ Archiwum Główne Akt Dawnych Rada Stanu i Rada Ministrów Księstwa Warszawskiego [dalej: ARS] akta spraw, sygn. 115, s. 1-2; Protokoły Rady Stanu Księstwa Warszawskiego, t. I, cz. 1-2, wyd. B. Pawłowski, Torun 1960-1962; t. II, cz. 1-2, wyd. B. Pawłowski, T. Mencel, Toruń 1965-1968; t. III, cz. 1-2, wyd. T. Mencel, M. Kallas, Warszawa 1995-1996, t. I, cz. 1, s. 49-51.

4 AGAD ARS akta spraw, sygn. 115, s. 1-2; Dziennik Praw [Księstwa Warszawskiego], t. I, nr 1, s. 1-2; Protokoty..., t. I, cz. 1, s. 49-51; Kodeks postępowania sądowego cywilnego francuskiego, Warszawa [1807], s. 178-182 (art. 580-593). Być może analiza szczątkowych pozostałości po aktach sądowych, a szczególnie akt Trybunału Cywilnego Kaliskiego, pozwoliłaby na rozstrzygnięcie wątpliwości dotyczących rozumienia pojęcia żołnierzy „niemających majątku”. Obecnie, ze względu na brak dostępu do archiwaliów z powodu epidemii, jest to niemożliwe. W opinii z 30 czerwca 1809 r. minister sprawiedliwości Łubieński użył jeszcze innego określenia - „,wojskowych nie mających własności”, które wyraźnie wskazywało na szerokie rozumienie pojęcia majątku, nieograniczonego jedynie do nieruchomości (AGAD ARS akta spraw, sygn. 115, s. 6). Szerzej o postępowaniu egzekucyjnym i moratoriach: T. Królasik, Francuski model postępowania egzekucyjnego w Księstwie Warszawskim i w Królestwie Polskim w latach 1808-1823 (niepublikowana rozprawa doktorska), Warszawa 2018, passim. 
Pominięto więc pozostałe grupy, które zostały objęte przepisami uchwały Komisji Rządzącej, czyli osoby, na których ciążył obowiązek zaopatrzenia armii, jak również osoby niepozostające w służbie wojskowej, ale na stałe przebywające przy oddziałach wojska, a także funkcjonariuszy państwowych przebywających w ramach pełnienia swoich obowiązków za granicą. Jednakże wobec kategorycznego tonu dekretu z 12 grudnia 1807 r. trudno wnioskować, że wobec tych kategorii osób postanowienia uchwały Komisji Rządzącej nie zostały uchylone. Celem tej regulacji było bowiem przywrócenie „biegu sprawiedliwości zatrzymanego w czasie wojny uchwałą Komisji Rządzącej”, a wolą króla było, ,ażeby wszelkie magistratury sądowe rozpoczęły w czasie jak najprędszym sądzenie wszelkich spraw dotąd zawieszonych, zaległych i rozpoczętych". Natomiast normy regulujące postępowanie egzekucyjne z żołdu niewątpliwie odnosiły się tylko do żołnierzy ${ }^{5}$.

Kolejny raz sprawa ochrony żołnierzy przed skutkami prowadzonych z ich udziałem postępowań sądowych pojawiła się czasie wojny z Austrią w $1809 \mathrm{r}$. $\mathrm{Z}$ wnioskiem o wstrzymanie takich postępowań wystąpił do Rady Stanu zastępca ministra wojny generał Kajetan Hebdowski. Rada Stanu wówczas faktycznie zastępowała monarchę. Generał Hebdowski powoływał się na informacje otrzymywane od żołnierzy, że sądy w czasie ich nieobecności wydawały wyroki w sprawach, w których byli uczestnikami. Zastępca ministra wojny wskazywał na przykłady innych państw, które miały zawieszać postępowania z udziałem żołnierzy na czas działań wojennych, oraz na uchwałę Komisji Rządzącej z dnia 30 stycznia 1807 r. Prosił w związku z tym o decyzję Rady Stanu. Ta przekazała wniosek gen. Hebdowskiego ministrowi sprawiedliwości, aby się do tej sprawy odniósł ${ }^{6}$.

Fryderyk Łubieński przedstawił swoją opinię na piśmie i ustnie na posiedzeniu Rady Stanu w dniu 30 czerwca 1809 r. Sprzeciwił się w niej szczególnemu traktowaniu żołnierzy w postępowaniu sądowym, twierdząc, że ,gdyby dozwolone były wyjątki, każdy urzędnik wymawiałby się obowiązkiem, każdy żołnierz wojną, każdy wyrobnik pracą”. Uważał, że nie można było stosować takich rozwiązań, jakie przyjęła Komisja Rządząca, bo działała ona w okresie kształtowania się nowych władz. W czasie, gdy działały organy konstytucyjne, nie powinno się stosować takich nadzwyczajnych środków, tym bardziej że w obowiązującym prawie były przepisy i instytucje wystarczająco chroniące interesy prawne żołnierzy. Minister wskazał na działających przy armii, a mianowanych przez dowództwo urzędników stanu cywilnego, notariuszy, a przede wszystkim audytorów, którzy mogli przyjmować zeznania w ramach postępowań cywilnych i pozostawali w stałych relacjach $\mathrm{z}$ sądami. Dlatego postępowania sądowe z udziałem żołnierzy mogły się normalnie

\footnotetext{
${ }^{5}$ Dziennik Praw, t. I, nr 1, s. 1-2; Protokoty..., t. I, cz. 1, s. 49-51.

${ }^{6}$ AGAD ARS akta spraw, sygn. 115, s. 4; Protokoty..., t. II, cz. 2, s. 52.
} 
toczyć, tym bardziej że sądy brały pod uwagę to, iż z uwagi na wojnę należało uwzględnić wydłużenie terminów na podjęcie kroków prawnych przez żołnierzy ${ }^{7}$.

Rada Stanu zgodziła się z Łubieńskim, uznając, że nie można zastosować powszechnego zawieszenia postępowań sądowych wobec żołnierzy. Poprosiła jednak ministra o przygotowanie takiego rozwiązania zgodnego z prawem, aby uchronić żołnierzy przed możliwością wydania przeciw nim wyroków zaocznych z powodu ich niestawienia się przed sądem (,dekreta in contumaciam”), gdy nie zostali powiadomieni o toczącym się z ich udziałem postępowaniu sądowym i nie mogli złożyć wyjaśnień przed audytorami wojskowymi. Z wypowiedzi Łubieńskiego i referendarza Onufrego Wyczechowskiego na posiedzeniu Rady wynikało bowiem, że na gruncie obowiązującego prawa znalezienie takiego środka było możliwe ${ }^{8}$.

Rozwiązanie wskazał minister w piśmie do Rady Stanu z dnia 3 lipca 1809 r. i w swoim wystąpieniu na jej sesji tego samego dnia. Zaproponował mianowicie, aby zarządzić, żeby art. 21 francuskiego kodeksu postępowania cywilnego mogły stosować wszystkie sądy cywilne Księstwa Warszawskiego. Według tego przepisu sędziowie pokoju mogli, wydając wyrok zaoczny z powodu nieobecności pozwanego, wyznaczyć mu termin na złożenie opozycji, czyli sprzeciwu, wystarczająco długi, aby pozwany mógł ją złożyć. Z takiej możliwości sędziowie pokoju mogli korzystać na wniosek osób bliskich, które informowały sąd o tym, że pozwany nie wiedział o toczącym się postępowaniu, lub z urzędu, gdy sami sędziowie mieli taką wiedzę. W razie, gdyby takie okoliczności nie zaszły, a do przedłużenia terminu nie doszło i zapadł wyrok zaoczny, pozwany mógł bez względu na upływ terminu wystąpić z opozycją przeciwko niemu, jeżeli wykazałby, że nie wiedział o toczącej się sprawie z powodu nieobecności lub ciężkiej choroby. Rozciągnięcie mocy obowiązującej tego przepisu na wszystkie sądy cywilne miało trwać przez cały okres wojny9.

Propozycja ministra Łubieńskiego zyskała akceptację Rady Stanu i na sesji w dniu 4 lipca 1809 r. przybrała formę uchwały. Podejmując ją, Rada Stanu działała na podstawie specjalnych pełnomocnictw udzielonych jej przez Fryderyka Augusta 25 marca i 20 kwietnia 1809 r. Król zresztą uchwałę tę zatwierdził dekretem z dnia 22 lipca 1809 r. Analiza jej art. 1 prowadzi do wniosku, że rozciągnięcie stosowania art. 21 kodeksu postępowania cywilnego na wszystkie sądy cywilne odnosiło się nie tylko do żołnierzy, ale także do wszystkich podmiotów mogących występować

\footnotetext{
${ }^{7}$ AGAD ARS akta spraw, sygn. 115, s. 4-6; Protokoty..., t. II, cz. 2, s. 58.

${ }^{8}$ Protokoty..., t. II, cz. 2, s. 58.

9 AGAD ARS akta spraw, sygn. 115, s. 7-8; Protokoły..., t. II, cz. 2, s. 58; Code de procédure civile, Paris 1806, s. 7; Kodeks postępowania sądowego..., s. 8. Na złożenie opozycji od wyroku zaocznego przysługiwał w zasadzie termin ośmiu dni, przy czym w sądach pokoju termin wynosił tylko trzy dni. Zob. W. Sobociński, Historia..., s. 265; Ogólna ordynacja sądowa dla państw pruskich, thum. i oprac. I. Stawiarski, t. II, Warszawa 1809, s. XLVI-LI.
} 
w postępowaniach cywilnych. W art. 1 zabrakło jednak wyraźnego stwierdzenia, że zakres tego unormowania dotyczy jedynie sytuacji prawnej żołnierzy. Prawdopodobnie twórcy uchwały nie zdawali sobie z tego sprawy, czego dowodem był przebieg prac przygotowawczych do uchwalenia tego aktu. Ich intencje zostały wyrażone w preambule do uchwały, w której mowa była o „wojskowych”, którzy mieli ,prawo oczekiwać od rządu, iż ich zasłoni od krzywdy, którą by ponieść mogli z zaocznego postępowania w sądach przeciwko sobie"10.

Niewiele wiadomo na temat stosowania uchwały Rady Stanu z dnia 4 lipca 1809 r. W związku z tym intersująca jest sprawa płk. Ignacego Zielińskiego, która została poruszona na sesji Rady Stanu w dniu 28 października 1809 r. Oficer ten, uczestnik działań wojennych przeciwko Austrii, żalił się, że sądy nie zważając na jego nieobecność, nie chciały wstrzymywać postępowań, w których był stroną. Zarzuty pułkownika, który pełnił wówczas obowiązki komendanta placu w Krakowie, znamy z drugiej ręki, poza tym zrelacjonowane zostały w sposób bardzo skrótowy. Nie wiadomo przede wszystkim przed jakim sądem czy też sądami toczyły się sprawy z udziałem Zielińskiego ani na jakim etapie postępowania te się znajdowały. Prawdopodobnie pretensje pułkownika były bezprzedmiotowe, bo żalił się, że nie miał możliwości „dokładnej obrony”, gdyż sądy „wstrzymywać nie chcą rozsądzenia rozpoczętych już procesów". Jak z tego wynika, Zieliński liczył na zawieszenie toczących się przeciw niemu postepowań. Jednak na podstawie uchwały Rady Stanu z dnia 4 lipca 1809 r. sądy takiej możliwości nie miały, mogły jedynie, wydając wyrok zaoczny, wyznaczyć odpowiedni czas na złożenie opozycji ${ }^{11}$.

W sprawę Zielińskiego zaangażował się sam minister wojny Józef Poniatowski, pisząc list do Rady Stanu z prośbą o przychylność wobec niego. Rada nie podjęła decyzji w tej sprawie, a wniosek pułkownika przekazała do rozpatrzenia ministrowi sprawiedliwości. Nie ma jednak informacji, jak zakończyło się postępowanie wobec Zielińskiego. Nie znamy też stanowiska Łubieńskiego, ale jest mało prawdopodobne, biorąc pod uwagę jego pryncypialny stosunek do niezależności sądów i niezawisłości sędziowskiej, aby w jakiś sposób interweniował w tej sprawie ${ }^{12}$.

${ }^{10}$ AGAD ARS akta spraw, sygn. 115, s. 7-12; Protokoly..., t. II, cz. 2, s. 71; Ustawodawstwo Księstwa Warszawskiego, wyd. W. Bartel, J. Kosim, Rostocki, t. I-IV, Warszawa 1964-1969, t. IV, s. 145-146; W. Sobociński, Historia..., s. 265; M. Krzymkowski, Rada Stanu Księstwa Warszawskiego, Poznań 2011, s. 236-241.

${ }_{11}$ Protokoły..., t. II, cz. 2, s. 246; Ignacy Zieliński (1781-1835) był dowódcą 5., 6. i 12. pułków piechoty Księstwa Warszawskiego, w listopadzie 1810 r. został zwolniony ze służby. Zob. E. Rastawiecki, Słownik malarzów polskich tudzież obcych w Polsce osiadlych lub czasowo w niej przebywajacych, t. III, Warszawa 1857, s. 89-90.

12 Protokoty..., t. II, cz. 2, s. 246; T. Mencel, Feliks Łubieński minister sprawiedliwości Księstwa Warszawskiego (1758-1848), Warszawa 1952, s. 73; M. Krzymkowski, Niezawisłość sędziowska w Księstwie Warszawskim [w:] T. Maciejewski, W. Zalewski (red.), Kara kryminalna, perspektywa historyczna i penologiczna, Gdańsk 2019, s. 165. 
Ostatni raz kwestia rozciągnięcia szczególnej ochrony prawnej w postępowaniach sądowych nad żołnierzami pojawiła się w związku z wojną z Rosją. W piśmie z 9 kwietnia 1812 r. minister wojny Józef Poniatowski wystąpił do Rady Stanu z wnioskiem o zwrócenie się do króla o wydanie dekretu zawieszającego postępowania sądowe wobec żołnierzy i urzędników administracji wojskowej. Jak pisał w swoim memoriale Poniatowski, do sformułowania takiej prośby skłoniły go informacje od oficerów i urzędników o tym, że w związku z relokacją wojsk w tym gorącym okresie nie byli w stanie dopilnować swoich spraw w sądach. Wniosek przedstawił na posiedzeniu Rady Ministrów w dniu 10 kwietnia 1812 r. Ta, uznając go za pilny, przesłała go Radzie Stanu ${ }^{13}$.

Jednakże wniosek ministra wojny nie był kompletny, gdyż nie zawierał najważniejszego elementu, czyli projektu dekretu. Dlatego sekretarz generalny Rady Stanu Stanisław Grabowski poprosił Ministerstwo Wojny o przygotowanie takiego projektu. Odpowiedzią na to było pismo z dnia 12 kwietnia 1812 r. płk. Jana Benneta, sekretarza generalnego Ministerstwa Wojny, i dołączony do niego projekt dekretu. Redaktorem tego projektu był właśnie pułkownik Bennet, starając się umieścić w formułach prawnych zamysły naczelnego wodza. Co ciekawe, intencją pomysłodawców było zachowanie przyszłego dekretu w tajemnicy poprzez nieogłaszanie jego treści w czasopismach ${ }^{14}$.

W projekcie zaskakująca była część, którą można określić jako preambułę, w której jasno zostały określone plany państwa dotyczące prowadzenia kolejnej wojny (,„zważywszy okoliczności zapowiadające bliską wojnę, wśród której oficerowie i urzędnicy wojska naszego Księstwa Warszawskiego i wszelkiego stopnia wojskowi zajęci obowiązkami powołania swego, nie mogą być w sposobności stawać i odpowiadać w sądach i jurysdykcjach krajowych...”). W zasadniczej części projektu dekretu zaproponowano wprowadzenie zakazu wszczynania procesów wobec żołnierzy i urzędników administracji wojskowej oraz zawieszenie postępowań sądowych z ich udziałem pod rygorem uznania wyroków wydanych $\mathrm{w}$ takich postępowaniach za nieważne ${ }^{15}$.

Projekt ten trafił do sekcji sprawiedliwości Rady Stanu. Sekcja miała go zaopiniować i przedstawić swoje wnioski Radzie Stanu. Zanim jednak trafił pod obrady sekcji, ta zwróciła się o jego ocenę do ministra sprawiedliwości Łubieńskiego. Minister w piśmie z dnia 15 kwietnia skrytykował pomysł zawieszenia postępowań

${ }^{13}$ AGAD ARS akta spraw, sygn. 115, s. 13; AGAD Rada Ministrów Księstwa Warszawskiego [dalej: ARM], ks. kanc. sygn. 71, s. 289. Taki tryb procedowania nad wnioskiem Poniatowskiego wynikał z przepisów dekretu z dnia 19 września 1810 r. o organizacji Rady Stanu. Ministrowie podczas nieobecności króla w kraju mogli przedstawiać Radzie Ministrów projekty dekretów, które uważali za pilne. Jeżeli ta zgodziła się ze zdaniem ministra, to dopiero wtedy mógł on wnieść projekt do Rady Stanu. Dziennik Praw, t. II, nr 22, s. 382; M. Krzymkowski, Rada Stanu ..., s. 157.

${ }^{14}$ AGAD ARS akta spraw, sygn. 115, s. 14-15; AGAD ARS ks. kanc. sygn. 91, s. 500.

${ }^{15}$ AGAD ARS akta spraw, sygn. 115, s. 14-15. 
sądowych z udziałem żołnierzy i urzędników administracji wojskowej. Uważał, że właściwym rozwiązaniem było, podobnie jak w 1809 r., skorzystanie z możliwości, jakie dawał art. 21 kodeksu postępowania cywilnego. Zwrócił także uwagę na art. 446 tego kodeksu, który miał zastosowanie do osób pozostających w służbie lądowej lub morskiej, a także tych, które przebywały na polecenie władz w misjach zagranicznych. Osoby takie miały przedłużony czas na złożenie apelacji od wyroków o rok. Argumentem za niestosowaniem nadzwyczajnych rozwiązań, według ministra sprawiedliwości, był przykład Francji, która prowadziła przez wiele lat wojny, nie stosując jednak szczególnej ekscepcji dla żołnierzy. W podobnej sytuacji byli przecież żołnierze polscy walczący od dłuższego czasu w Hiszpanii, wobec których również nie zastosowano zawieszenia postępowań cywilnych ${ }^{16}$.

Projekt Ministerstwa Wojny stał się przedmiotem dogłębnej analizy sekcji sprawiedliwości Rady Stanu. Gremium to dostrzegło podobieństwo tej propozycji do rozwiązań przyjętych przez Komisję Rządzącą w uchwale z dnia 30 stycznia 1807 r. Taką drogę rozwiązania tego problemu sekcja uznała za błędną, wychodząc z założenia, że sytuacja, w jakiej działała Komisja Rządząca, była nadzwyczajna, a organizacja państwa tymczasowa. Nie można było wobec tego stosować rozwiązań wówczas przyjętych do sytuacji, gdy system konstytucyjny państwa i prawo sądowe były w pełni ukształtowane. Sekcja sprawiedliwości zatem uznała, że nie można czynić wyjątków w przypadku tylko jednej grupy obywateli. W zasadniczej części założenia leżące u podstaw opinii sekcji były powtórzeniem stanowiska prezentowanego przez ministra sprawiedliwości Łubieńskiego wobec propozycji zawieszenia postępowań w stosunku do żołnierzy w czasie wojny z Austrią w 1809 r. ${ }^{17}$

Według sekcji sprawiedliwości w Kodeksie Napoleona, który obowiązywał na podstawie konstytucji w Księstwie Warszawskim, nie przewidziano żadnych tego typu wyjątków. Wskazanie na kodeks cywilny było wątpliwe z prawnego punktu widzenia, bo akt ten zawierał przecież normy prawa materialnego, a nie procesowego, do którego zakresu należało ewentualne zawieszenie postępowania. Sekcja w swojej argumentacji powtarzała za ministrem sprawiedliwości przykład Francji i sytuację żołnierzy polskich w Hiszpanii. Jak twierdzili członkowie sekcji sprawiedliwości, toczyło się wobec nich wiele postępowań i zapadło wiele wy-

${ }^{16}$ Minister Łubieński w swoim piśmie powtórzył dosłownie treść art. 446 kodeksu postępowania, w którym mowa była o osobach, „które użytemi będąc w czynnościach zewnętrznych na usłudze rządowej, nieprzytomnemi są na terytorium europejskim kraju”, co odnosiło się oczywiście do Francji, która oprócz metropolii posiadała liczne kolonie. Zob. AGAD ARS akta spraw, sygn. 115, s. 22-25; Kodeks postępowania sądowego..., s. 140.

17 AGAD ARS akta spraw, sygn. 115, s. 4-6, 15-21; AGAD ARS ks. kanc. sygn. 91, s. 500501; Protokoły..., t. II, cz. 2, s. 58. W skład sekcji sprawiedliwości Rady Stanu wchodzili radcy stanu Walenty Rzętkowski jako przewodniczący, Franciszek Grabowski i Franciszek Taczanowski oraz referendarze Michał Woźnicki i Antoni Wyczechowski. Zob. Protokoły..., t. III, cz. 2, s. 94; M. Krzymkowski, Rada Stanu..., s. 129-130. 
roków, które zostały im doręczone w sposób przewidziany w przepisach prawa. Mimo to żołnierze ci nie występowali ze skargami, co według sekcji znaczyło, że ten normalny sposób postępowania nie rodził ryzyka dla stron ${ }^{18}$.

Sekcja sprawiedliwości, powołując się na te przykłady, uznała, że nie było konieczności wprowadzania żadnych nadzwyczajnych rozwiązań w stosunku do żołnierzy wobec zbliżającej się wojny. Jedynie „dla spokojności wojskowych” zaproponowała rozwiązanie, które miało wyjść naprzeciw wnioskowi ministra wojny. Rozwiązaniem tym było wydanie dekretu zawierającego podobne normy jak te, które znalazły się w uchwale Rady Stanu z dnia 4 lipca 1809 r. Według sekcji sprawiedliwości przepisy tej uchwały spełniły swoje zadanie, czego dowodem miało być to, że żaden żołnierz „na poniesioną stratę nie narzekał”. W opracowaniu dla Rady Stanu znalazło się więc powołanie na art. 21 francuskiego kodeksu postępowania cywilnego i rozszerzenie możliwości jego stosowania także przez inne sądy oprócz sądów pokoju. Sekcja uznała, że przepis ten mógł mieć zastosowanie jedynie w sprawach, które nie zostały jeszcze wszczęte. W przypadku postępowań, które już się toczyły, miały obowiązywać zwykłe zasady - bo według sekcji ustanowieni byli w nich pełnomocnicy i obecność stron była zbędna. Żeby zapewnić równość stron, zaproponowano, aby także osoby cywilne, które były dłużnikami żołnierzy, mogły skorzystać z możliwości złożenia opozycji wobec wyroku zapadłego w czasie wojny ${ }^{19}$.

Stanowisko sekcji sprawiedliwości zostało zaprezentowane na posiedzeniu Rady Stanu w dniu 18 kwietnia 1812 r. Sprawozdawcą był radca stanu Franciszek Taczanowski. Oprócz referatu dotyczącego zawieszenia postępowań wobec żołnierzy i urzędników administracji wojskowej sekcja przedstawiła także projekt dekretu królewskiego w tej sprawie. Był on całkowicie odmienny od pierwotnego projektu, który został przygotowany w Ministerstwie Wojny, zgodny zaś z założeniami przyjętymi przez sekcję sprawiedliwości i sugestiami ministra sprawiedliwości. Nie znalazł się w nim jednak przepis o możliwości składania opozycji przez osoby cywilne będące dłużnikami żołnierzy. To zagadnienie sekcja pozostawiła do rozstrzygnięcia Radzie Stanu ${ }^{20}$.

Dyskusję na posiedzeniu Rady Stanu w dniu 18 kwietnia 1812 r. rozpoczął radca stanu Stanisław Staszic. Uznał on, że wobec argumentacji przedstawionej przez sekcję sprawiedliwości nie było powodu, aby przedsiębrać nadzwyczajne środki, których celem była ochrona żołnierzy w postępowaniach sądowych w czasie wojny. Staszic nie widział więc potrzeby wydawania przez króla dekretu w wersji proponowanej przez ministra wojny ani nawet według projektu przygotowanego

${ }^{18}$ AGAD ARS akta spraw, sygn. 115, s. 16-21; AGAD ARS ks. kanc. sygn. 91, s. 500-501.

19 AGAD ARS akta spraw, sygn. 115, s. 16-21; AGAD ARS ks. kanc. sygn. 91, s. 500-502.

${ }^{20}$ AGAD ARS akta spraw, sygn. 115, s. 20-21, 26-34; AGAD ARS ks. kanc. sygn. 91, s. 500502. 
przez sekcję sprawiedliwości. Odmiennego zdania był radca stanu Walenty Rzętkowski, wskazując na szczególne okoliczności, które mogły zaistnieć w czasie wojny, a które uniemożliwiłyby doręczenie korespondencji sądowej. Wśród takich zagrożeń obawiał się szczególnie okupacji terytorium państwa przez obce wojska czy oblężenia twierdz. Staszic słusznie odpowiedział na to, że w takim razie nie należałoby różnicować sytuacji żołnierzy i cywilów, bo opisane przez Rzętkowskiego ograniczenia dotyczyłby zarówno jednych, jak i drugich ${ }^{21}$.

W toku dyskusji wyjaśniono, że celem projektu nowego dekretu nie było wstrzymywanie procesów z udziałem żołnierzy, a jedynie umożliwienie im złożenia po wojnie opozycji wobec wyroków zapadłych przeciwko nim. Osoby cywilne nie powinny zostać objęte tą regulacją z tego powodu, że rzadko zdarzało się, aby nie można było im doręczyć korespondencji sądowej. Ostatecznie Rada Stanu przyjęła, z drobnymi odmianami, projekt w wersji proponowanej przez sekcję sprawiedliwości i przesłała go królowi wraz ze swoją opinią, również zbieżną ze stanowiskiem tej sekcji ${ }^{22}$.

Temu projektowi zdecydowanie sprzeciwił się minister wojny Józef Poniatowski. Nie był on obecny na posiedzeniu Rady Stanu w dniu 18 kwietnia $1812 \mathrm{r}$. Na temat stanowiska Rady wypowiedział się w piśmie do niej z dnia 21 kwietnia 1812 r. Skrytykował zastosowanie art. 21 kodeksu postępowania cywilnego, bo jak twierdził - nie wstrzymywałoby to biegu postępowań przeciwko żołnierzom, co było celem jego propozycji z 9 kwietnia 1812 r. Rozwiązanie przyjęte przez Radę Stanu powodowałoby jego zdaniem konieczność przedsiębrania przez żołnierzy dwóch postępowań - pierwszego o wzruszenie wyroku i drugiego o merytoryczne rozstrzygnięcie sprawy. Dlatego ponownie wzywał, aby postępowania wobec żołnierzy i osób związanych z armią zostały zawieszone ${ }^{23}$.

Poniatowskiemu nie udało się przeforsować swego stanowiska, czego wyrazem był dekret z 15 lipca 1812 r. Z niewiadomych powodów dekret ten miał treść ograniczoną w stosunku do projektu przygotowanego przez Radę Stanu na posiedzeniu w dniu 18 kwietnia 1812 r. Brakowało w nim bowiem art. 2, czyli przepisu przechodniego, w którym wyraźnie zakazano stosować normy dekretu do spraw wszczętych przed jego wydaniem. Do usunięcia tego przepisu doszło już po przekazaniu opinii Rady Stanu z sesji z dnia 18 kwietnia 1812 r. i projektu dekretu królowi, bowiem aż do sesji w dniu 28 lipca 1812 r. sprawa ta nie była przedmiotem obrad Rady Stanu. Nie wiadomo natomiast, dlaczego nastąpiło takie okrojenie treści projektu dekretu ${ }^{24}$.

${ }^{21}$ AGAD ARS ks. kanc. sygn. 91, s. 503.

22 AGAD ARS akta spraw, sygn. 115, s. 26-34; AGAD ARS ks. kanc. sygn. 91, s. 504.

${ }^{23}$ AGAD ARS akta spraw, sygn. 115, s. 35; AGAD ARS ks. kanc. sygn. 91, s. 495.

${ }^{24}$ AGAD ARS ks. kanc. sygn. 91, s. 676-677; Dziennik Praw, t. IV, nr 46, s. 336-337. 
W zasadzie więc dekret z 15 lipca 1812 r. był powtórzeniem uchwały Rady Stanu z dnia 4 lipca 1809 r. W porównaniu jednak do tego pierwszego aktu nastąpiło wyraźne ograniczenie dobrodziejstw płynących z rozciągnięcia stosowania art. 21 kodeksu postępowania cywilnego na wszystkie sądy jedynie do żołnierzy i urzędników administracji wojskowej („dla osób wojskowych i urzędników do wojska przywiązanych, a w czynnej istotnie służbie zostających”). Można domniemywać, że członkowie sekcji sprawiedliwości, opracowując projekt dekretu królewskiego, zdali sobie sprawę z tego, że uchwała Rady Stanu z dnia 4 lipca 1809 r., wbrew jej intencjom, mogła mieć zbyt szerokie zastosowanie ${ }^{25}$.

Po raz ostatni problem ochrony osób uczestniczących w wojnie w postępowaniach sądowych pojawił się pod koniec grudnia 1812 r., a więc w okresie, gdy resztki wojsk napoleońskich wycofywały się z Rosji. Na żądanie Napoleona Rada Generalna Konfederacji Generalnej Królestwa Polskiego w dniu 20 grudnia 1812 r. ogłosiła wezwanie do pospolitego ruszenia. Chcąc zabezpieczyć szlachtę, która wzięłaby w nim udział, Rada zwróciła się do króla o rozciągnięcie na uczestników pospolitego ruszenia mocy obowiązującej przepisów dekretu z dnia 15 lipca $1812 \mathrm{r}$. Fryderyk August powziął wątpliwości co do zastosowania takiego rozwiązania, dlatego w dekrecie z dnia 30 grudnia 1812 r. zwrócił się do Rady Stanu o rozstrzygnięcie kilku kwestii z tym związanych. O znaczeniu, jakie dla Fryderyka Augusta miało rozwiązanie tych problemów, świadczył fakt nakazania Radzie zebrania się na sesji, nawet gdyby miała to być sesja nadzwyczajna, oraz zobowiązanie wszystkich ministrów do uczestnictwa w niej. Tak kategoryczne dyspozycje króla wobec organów państwa miały charakter wyjątkowy. Rada Stanu miała wyjaśnić, czy wystarczającym środkiem do ochrony prawnej uczestników pospolitego ruszenia było zastosowanie do nich mocy obowiązującej dekretu z dnia 15 lipca $1812 \mathrm{r}$. Król miał wątpliwości, czy wobec specyfiki pospolitego ruszenia nie należałoby bardziej precyzyjnie określić zakresu podmiotowego tej regulacji. Rada miała też odpowiedzieć na pytanie, czy w związku z zagrożeniem państwa nie należałoby wydać aktu prawnego kompleksowo regulującego zasady postępowań sądowych wobec wszystkich grup ludności ${ }^{26}$.

Prace Rady Stanu wobec pogarszającego się położenia państwa i zagrożenia ze strony wojsk rosyjskich poszły w kierunku przygotowania propozycji prawnych rozwiązań odnoszących się do tej ostatniej kwestii, uznając sprawę szczególnej ochrony uczestników pospolitego ruszenia za element szerszego problemu dotyczącego wszystkich mieszkańców Księstwa. Efektem tego był przygotowany przez

${ }^{25}$ Dziennik Praw, t. IV, nr 46, s. 336-337; W. Sobociński, Historia..., s. 265.

26 AGAD ARS akta spraw, sygn. 114, s. 71-74, 103-106; „Gazeta Poznańska” nr 105 z 30 grudnia 1812 r.; J. Czubaty, Księstwo Warszawskie (1807-1815) [Warszawa 2011], s. 506. 
Radę Stanu dekret z dnia 15 stycznia 1813 r. o częściowym zawieszeniu postępowań sądowych i egzekucyjnych w związku z zagrożeniem niektórych departamentów ${ }^{27}$.

Władze państwowe Księstwa Warszawskiego (także przed jego formalnym utworzeniem) starały się zabezpieczyć interesy żołnierzy w postępowaniach sądowych. Najszerszą ochroną zostali oni objęci na podstawie uchwały Komisji Rządzącej z dnia 30 stycznia 1807 r. Później organy państwa jeszcze dwukrotnie wydawały przepisy, których celem była prawna ochrona żołnierzy w postępowaniach sądowych, jednakże ani uchwały Rady Stanu z dnia 4 lipca 1809 r., ani dekret królewski z dnia 15 lipca 1812 r. nie zawierały norm, na podstawie których takie postępowania zostałyby zawieszone.

\title{
SPECIAL LEGAL PROTECTION OF SOLDIERS \\ IN THE COURSE OF COURT PROCEEDINGS \\ AND ENFORCEMENT PROCEEDINGS IN THE DUCHY OF WARSAW
}

\begin{abstract}
The state authorities of the Duchy of Warsaw tried to secure the interests of soldiers in court proceedings. Among the acts containing provisions which protected soldiers was a regulation of the Ruling Commission of the $30^{\text {th }}$ of January 1807, a regulation of the Council of State of the $4^{\text {th }}$ of July 1809 , and a royal decree of the $15^{\text {th }}$ of July 1812 . The provisions of the Ruling Commission provided the most extensive source of protection. The two following acts provided for the possibility of employing article 21 of the civil procedure in all proceedings.

Keywords: Duchy of Warsaw, Frederick August I, Council of State, decree, Ruling Commission, army of Duchy of Warsaw, War of 1812, Austro-Polish War

${ }^{27}$ AGAD ARS ks. kanc. sygn. 92, s. 613-624 (sesje z 5 i 6 stycznia 1813 r.); AGAD ARS akta spraw, sygn. 114, s. 75-114; Ustawodawstwo..., t. IV, s. 92.
\end{abstract}

